\title{
Environmental fluctuation and shifting predation pressure contribute to substantial variation in early marine survival of steelhead
}

\author{
Megan E. Moore ${ }^{1, *}$, Barry A. Berejikian ${ }^{1}$, Correigh M. Greene ${ }^{2}$, Stuart Munsch ${ }^{3}$ \\ ${ }^{1}$ Environmental and Fisheries Sciences, National Marine Fisheries Service, \\ National Oceanic and Atmospheric Administration, 7305 Beach Drive East, Port Orchard, Washington 98366, USA \\ ${ }^{2}$ Fish Ecology Division, National Marine Fisheries Service, National Oceanic and Atmospheric Administration, \\ 2725 Montlake Boulevard East, Seattle, Washington 98112, USA \\ ${ }^{3}$ Ocean Associates Inc., Under Contract to National Marine Fisheries Service, 4007 North Abingdon Street, Arlington, \\ Virginia 22207, USA
}

\begin{abstract}
Steelhead Oncorhynchus mykiss smolts must migrate through distinct freshwater, estuarine, and coastal habitats, each with unique biological and physical characteristics, on their route from natal streams to the ocean to complete their life cycle. Fewer than $15 \%$ of steelhead smolts survived their migration from the Nisqually River through Puget Sound to the Pacific Ocean from 2006 to 2009 and in 2014. Rapid smolt migration coupled with evidence of smolt mortality at harbor seal Phoca vitulina haulouts during 2014 indicated that predation by pinnipeds was an important source of mortality. When Puget Sound temperatures increased with the Northeast Pacific marine heat wave from late 2014 to 2016, steelhead smolt survival probabilities increased to $38 \%$ in 2016 and 2017, then decreased again as Puget Sound water temperatures cooled. Many ecological changes accompanied the increased marine temperatures, including the increased abundance of northern anchovy Engraulis mordax in Puget Sound. The years of lowest smolt mortality coincided with abundant larval and post-larval anchovy during the previous year; and we provide data from telemetered harbor seals and steelhead indicating that the resulting high abundance of age-1+ anchovy provided an alternative prey source for predators of migrating steelhead smolts. Identification of ecological mechanisms that drive patterns in the survival of Endangered Species Act-threatened steelhead provides critical understanding of the systems within which management strategies must operate.
\end{abstract}

KEY WORDS: Climate $\cdot$ Predator-prey dynamics $\cdot$ Steelhead survival $\cdot$ Migration $\cdot$ Oncorhynchus mykiss

\section{INTRODUCTION}

Marine ecosystems are fundamentally influenced by broad-scale climate patterns. Indices of ocean climate variability, such as the Pacific Decadal Oscillation (PDO), El Niño-Southern Oscillation, and North Pacific Gyre Oscillation, have been linked to fluctuations in marine species at various trophic levels (Brodeur et al. 1985, Clark \& Hare 2002, Menge et al.

*Corresponding author: megan.moore@noaa.gov
2009, Keister et al. 2011), including marine survival patterns of anadromous Pacific salmon (Oncorhynchus spp.; Mantua et al. 1997, Hare et al. 1999, Malick et al. 2017) and steelhead O. mykiss (Welch et al. 2000, Sobocinski et al. 2020). Patterns of association between salmon survival and ocean environmental conditions are inherently difficult to characterize, because relationships between physical and biological ecosystem components can shift over time

Outside the USA () The US Government 2021. Open Access under Creative Commons by Attribution Licence. Use, distribution and reproduction are unrestricted. Authors and original publication must be credited. 
(Beamish et al. 2004, Kilduff et al. 2014, Litzow et al. 2018) and space (Mueter et al. 2002, Teo et al. 2009, Sharma et al. 2013). A single salmonid cohort encounters diverse marine ecosystems (i.e. estuary, nearshore, continental shelf, open ocean), each with its own suite of physical and biological processes and inherent climate-survival linkages. Ecosystem dynamics involving both bottom-up and top-down control of survival patterns near the point of ocean entry are increasingly being considered as important components of the marine survival equation (Sydeman et al. 2013, Wells et al. 2017, Sobocinski et al. 2020). Understanding the influence of climate variation on interactions among living marine resources is vital to proper consideration of ecosystem-based management strategies.

Declines in the abundance of several anadromous Pacific salmonid species within the 'Salish Sea' (the network of inland waters of British Columbia [Canada] and the state of Washington [USA] extending from the northern Strait of Georgia to the southern boundary of Puget Sound) over the past 3 to 4 decades appear linked with conditions they experience soon after marine entry. Intra-specific survival trends for populations of coho salmon $O$. kisutch and steelhead indicate greater coherence within Puget Sound than with population groups from other regions of the eastern Pacific, implicating local marine ecosystem factors (Zimmerman et al. 2015, Kendall et al. 2017). Pink salmon O. gorbuscha, which migrate to marine waters soon after emergence and at the smallest size of any Pacific salmon, increasingly comprise a greater proportion of total salmon abundance in Puget Sound (Losee et al. 2019), suggesting that salmonids with different ecological requirements may be differentially influenced by major changes in the Puget Sound ecosystem (Ruggerone \& Goetz 2004).

Smolts of Puget Sound steelhead, listed as threatened under the Endangered Species Act (72 FR 26722), enter the marine environment in mid-spring at a relatively large body size (approximately 140$220 \mathrm{~mm}$ fork length), migrate very quickly through Puget Sound, prefer open water to nearshore environments, and exhibit very consistent interannual migratory behavior patterns (Moore et al. 2015). Predation in the early marine environment has been identified as a predominant mortality mechanism based on consistently high mortality rates over a short migratory time period, observed for populations throughout the region over multiple years (2006-2009 and 2014: Moore et al. 2015, Moore \& Berejikian 2017). During this period of high mortality, harbor seal Phoca vitulina predation was evident from acoustic tag detection patterns in large river estuaries and at rocky haulouts in central and northern Puget Sound (Berejikian et al. 2016, Moore \& Berejikian 2017). A thorough predator assessment identified harbor seals as a likely predator of steelhead smolts in Puget Sound (Pearson et al. 2015), and scat analysis of Salish Sea samples confirm harbor seal consumption of steelhead during the steelhead outmigration period (Thomas et al. in press). Other potential warm-blooded predators of migrating steelhead smolts include harbor porpoise Phocoena phocoena and a few avian predators that consume fish prey of this size (cormorants [Phalacrocorax spp.], Caspian terns Sterna caspia, and loons [Gavia spp.]).

Increasing ocean temperatures associated with climate change have diverse and profound effects on the distribution and phenology of marine species (Doney et al. 2012, Poloczanska et al. 2016). Following the most recent assessment of early marine survival of Puget Sound steelhead (2014 outmigrants; Moore \& Berejikian 2017), the Northeast Pacific Ocean experienced a marine heat wave, which began as a large mass of warm water in late 2014 persisting through late 2015, followed by the strongest El Niño on record that lasted through 2016 (Di Lorenzo \& Mantua 2016, Jacox et al. 2018). Documented effects of the persistent warming on the California Current Large Marine Ecosystem at all trophic levels are numerous (Cavole et al. 2016, Daly et al. 2017, Peterson et al. 2017, Du \& Peterson 2018).

One of the most ecologically significant changes associated with the marine heat wave was a substantial expansion in the spawning and abundance of northern anchovy Engraulis mordax (hereafter anchovy) within the Salish Sea ecosystem (Duguid et al. 2019). During the heatwave, offshore anchovy reproduction that usually occurs in warm months (June and July) expanded to include typically colder months both earlier and later in the year (Auth et al. 2018). Anchovy larval development and survival require warmer water temperatures (Brewer 1976) than are typical during Puget Sound winters. Similar expansions in spawn timing and increased abundance have occurred during previous anomalously warm periods in the early 1980s (Brodeur et al. 1985, Doyle 1995) and in 2004 and 2005 (Brodeur et al. 2006). During the marine heat wave, anchovies moved northward, affecting food webs in the Pacific Ocean (Leising et al. 2015). Predation pressure can shift dramatically when species occupy habitats in which they are typically absent or in low abundance (Thompson et al. 2012, Friedland et al. 2017), disrupting patterns of salmon survival observed under more 
typical ecological conditions (Wells et al. 2017). Data from multiple independent sources indicate significant spikes in anchovy abundance in Puget Sound in 2016 and in other recent warm periods in the $20^{\text {th }}$ century (Duguid et al. 2019).

Correlations among abiotic environmental conditions and salmon and steelhead survival are of much greater value where empirically linked to ecological mechanisms. Here we assessed how changing environmental conditions before, during, and after the North Pacific marine heat wave may have influenced the early marine survival of steelhead by shifting the predator-prey dynamics between harbor seals and migrating steelhead. First, we updated the steelhead smolt early marine survival time series, adding 6 additional years of data from the same wild steelhead population and same acoustic telemetry network previously documented (Moore et al. 2015). Second, we quantified the relationship between Pacific Ocean temperatures, Puget Sound temperatures, and steelhead early marine survival. Third, we evaluated ob- served effects of temperature on steelhead survival with respect to alternative prey availability (anchovy). Finally, we compared evidence of predation by harbor seals in 2 years representing the highest and lowest documented early marine steelhead survival in the recent time series, providing evidence of possible prey switching.

\section{MATERIALS AND METHODS}

\subsection{Steelhead smolt tagging}

Wild steelhead smolts were captured at a rotary screw trap at river kilometer (rkm) 19 in the Nisqually River (Fig. 1) during the smolt outmigration periods (April-June) of 2014 through 2019 (Table 1). Captured smolts were anesthetized, weighed, measured (fork length) onsite, and implanted with a Vemco V7 2L acoustic transmitter $(7 \times 15.5 \mathrm{~mm}, 69 \mathrm{kHz}, 30-90 \mathrm{~s}$ random ping interval) following surgical implantation

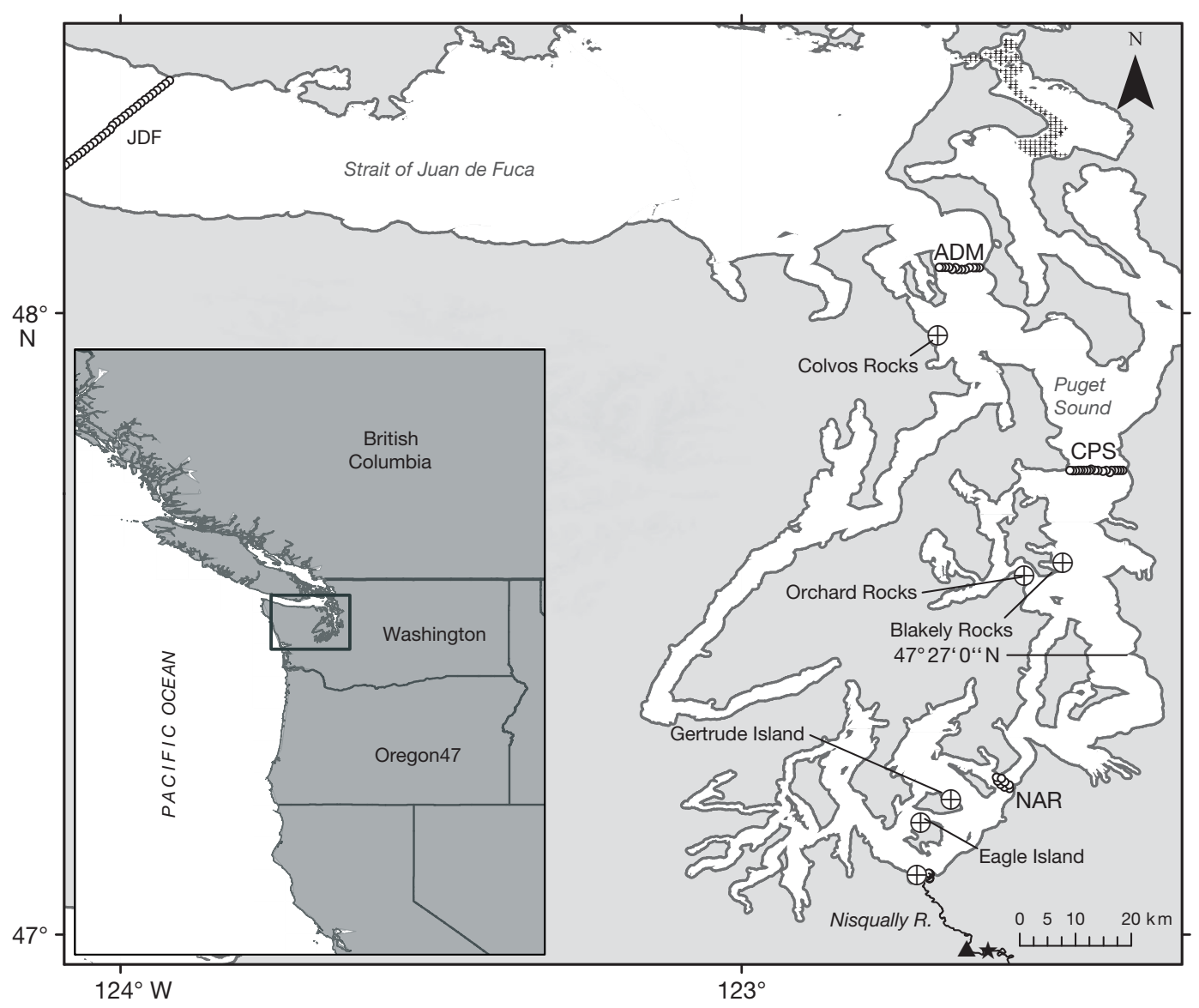

Fig. 1. Puget Sound and the Strait of Juan de Fuca, showing Nisqually River trap (black star), steelhead smolt release location (black triangle), and all moored telemetry receiver array locations (open circles) at the Tacoma Narrows (NAR), Central Puget Sound (CPS), Admiralty Inlet (ADM), and Strait of Juan de Fuca (JDF). Also shown are all harbor seal tagging locations (circle with cross) and Skagit Bay tow-net survey sites (small black crosses) 
Table 1. Number of tags, mean (SE) steelhead smolt fork length (FL), and migration year for steelhead smolts surgically implanted with acoustic telemetry transmitters in the Nisqually River, Washington, USA. Dates are given as mo/d

\begin{tabular}{|ccccc|}
\hline Year & $\begin{array}{c}\text { No. of } \\
\text { tags }\end{array}$ & $\begin{array}{c}\text { Mean FL } \\
(\mathrm{mm})\end{array}$ & $\begin{array}{c}\text { Mean body } \\
\text { mass (g) }\end{array}$ & $\begin{array}{c}\text { Tagging } \\
\text { date range }\end{array}$ \\
\hline 2014 & 100 & $197.3(26.5)$ & $73.6(34.0)$ & $4 / 27-5 / 24$ \\
2015 & 103 & $199.7(23.9)$ & $75.1(28.0)$ & $4 / 29-6 / 4$ \\
2016 & 150 & $201.3(24.1)$ & $76.5(28.9)$ & $4 / 25-6 / 2$ \\
2017 & 100 & $205.9(15.7)$ & $80.1(18.5)$ & $4 / 25-5 / 31$ \\
2018 & 210 & $210.1(23.7)$ & $90.5(32.0)$ & $4 / 28-6 / 6$ \\
2019 & 210 & $213.7(24.9)$ & $98.3(35.2)$ & $4 / 24-6 / 4$ \\
\hline
\end{tabular}

procedures outlined by Moore \& Berejikian (2017). All smolts were held for 18-24 h and then released at rkm 19. Similar handling, implantation, and release protocols were used for steelhead smolts tagged in 2006 through 2009 (see Moore et al. 2015).

\subsection{Fixed hydrophone locations}

Fixed hydrophones (those not attached to harbor seals; see Section 2.5) were used to estimate survival and detect tag movement patterns indicating smolts had been consumed and were being carried by harbor seals. The core array of 70 Vemco VR3 and VR4 hydrophones was deployed before the 2014 smolt migration and remained in place through the 2019 outmigration. This array included sub-arrays at the Tacoma Narrows (8 receivers; NAR), Central Puget Sound (19 receivers; CPS), Admiralty Inlet (13 receivers; ADM), and Strait of Juan de Fuca (30 receivers; JDF; maintained by the Ocean Tracking Network, Fig. 1). Six additional Vemco VR2W hydrophones were deployed at the same locations in the Nisqually estuary each year from 2014 to 2019.

\subsection{Environmental variables}

Two primary sources of temperature data were compiled to establish the relationship between broad-scale climate patterns and local temperature conditions in Puget Sound: (1) the PDO index (Mantua et al. 1997; http://research.jisao.washington.edu/ pdo/PDO.latest.txt) and (2) temperature data collected by King County from conductivity-temperature-depth (CTD) casts in CPS (http://green2.kingcounty.gov/ marine/Monitoring/OffshoreCTD). The PDO index reflects large-scale sea surface temperature in the North Pacific Ocean (Mantua \& Hare 2002). Monthly
PDO values were obtained from (https://oceanview. pfeg.noaa.gov/erddap/tabledap/cciea_OC_PDO. htmlTable?time,PDO) for all years of the study (20052019). Puget Sound temperature data were collected from monitoring stations in Puget Sound, operated by King County. Data from 10 stations (0-50 m depth) between $47^{\circ} 21^{\prime} 36^{\prime \prime} \mathrm{N}$ and $47^{\circ} 46^{\prime} 12^{\prime \prime} \mathrm{N}$ were averaged for each month and year. Mean annual PDO and mean annual Puget Sound temperatures were strongly and positively correlated during study years (correlation analysis, $\mathrm{r}=0.88$, $\mathrm{df}=13, \mathrm{p}<0.001$; Fig. 2), indicating strong coherence between ocean and inland water temperature patterns on an annual basis. Correlations among temperature indices and anchovy abundance trends (see Section 2.4) were assessed to investigate the influence of elevated temperature on steelhead mortality.

\subsection{Anchovy abundance}

Anchovy were sampled as part of a long-term monitoring of salmon, forage fish, and jellyfish in Puget Sound using a surface Kodiak trawl (Rice et al. 2011, 2012, Greene et al. 2015). Consistent anchovy abundance time series data from within Puget Sound are scarce (Duguid et al. 2019), and fortunately a continuous dataset near the steelhead migration corridor coincided with years in which steelhead mortality was quantified (Fig. 1). The monitoring consisted of Kodiak trawling using a spatially stratified design in subtidal neritic waters of Skagit Bay (5-30 m depth). The design attempted to sample 19 sites during monthly cruises between April and October. Among

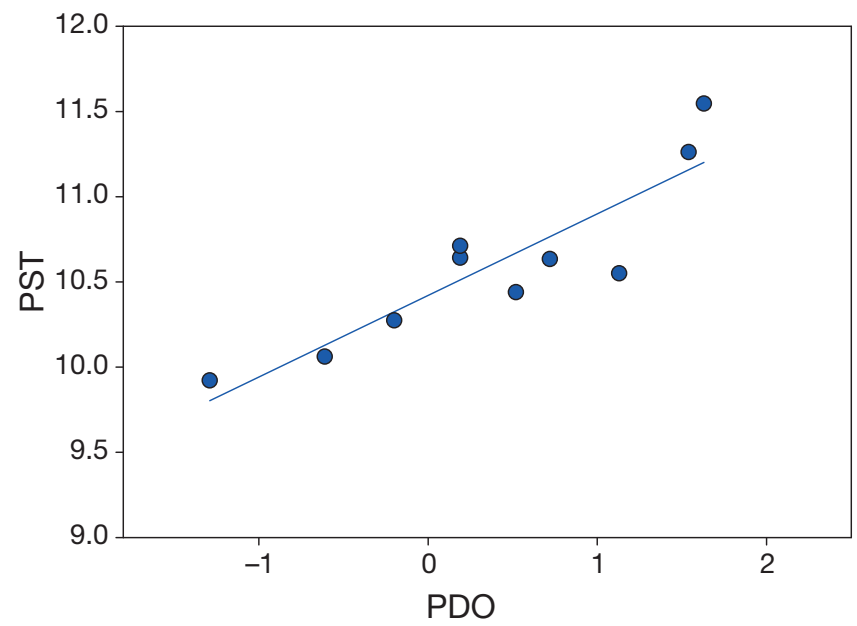

Fig. 2. Annual mean Puget Sound temperature (PST) is strongly, positively correlated with annual mean Pacific Decadal Oscillation (PDO) indices $(r=0.88)$ 
years, the total number of sites sampled ranged from 43 to 103 , with variation occurring due to logistic constraints (e.g. poor weather, vessel repairs). At each site, the trawl was towed between the 2 vessels for $10 \mathrm{~min}$ at a consistent speed ( 2 knots) among surveys. Although there was likely only minor variation in volume filtered, a flowmeter measured water volume filtered as a metric of sampling effort. Upon retrieval of the net, the crew measured abundance and biomass of each species captured, as well as individual lengths of a sample of up to 25 randomly selected fish.

The vast majority ( $>90 \%$ of catch) of captured anchovy were in larval or post-larval stages $(<50 \mathrm{~mm})$ throughout the field season, although some age-1+ fish were infrequently captured. Anchovies in coastal waters off Washington and Oregon typically spawn in summer months (Richardson 1973), but eggs and larvae can be found in the Salish Sea from April to August (Duguid et al. 2019). Eggs hatch in 2-4 d, depending on temperature (Bolin 1936). Adults can reach sexual maturity at age-1, when length averages $107 \mathrm{~mm}$, but most individuals mature after $2 \mathrm{yr}$ (Pike 1951). In surface-trawl survey catches from the Columbia River plume, age-1 anchovy ranged from 90 to $125 \mathrm{~mm}$ (Litz et al. 2008), and a multi-age sample of anchovies caught in a Puget Sound mid-water trawl survey (April 2016) had a bimodal distribution with modes at 105 and $145 \mathrm{~mm}$ (Duguid et al. 2019). Year class strength of marine fish populations is largely determined during early larval stages (Houde 1994, Bradford \& Cabana 1997), so we used an abundance index (described in Section 2.6.2) of larval and post-larval anchovies caught in Skagit Bay as an indicator for abundance of age-1 anchovies in Puget Sound in the following year.

\subsection{Harbor seal tagging and locations}

Harbor seal research activities were conducted under Marine Mammal Protection Act Research Permit 13430 issued by the National Marine Fisheries Service (Office of Protected Resources, Silver Spring, MD). Twelve adult harbor seals were captured at 3 haulouts (Colvos Rocks, Orchard Rocks, and Blakely Rocks) in 2014, and 16 seals were captured at 5 haulouts (Colvos Rocks, Orchard Rocks, Gertrude Island, Eagle Island, and Nisqually Estuary) in 2016 (Fig. 1; Table S1 in the Supplement at www.int-res. com/articles/suppl/m662p139_supp.pdf). Berejikian et al. (2016) described the tagging and monitoring procedures of harbor seals in 2014. Briefly, each seal was weighed, measured, and fitted with an instrument pack that was glued to the pelage with quick-set epoxy. Each pack contained (1) a Vemco mobile transceiver (VMT) receiver capable of detecting both the V7 tags (69 kHz) implanted in steelhead to quantify encounters, (2) a satellite-linked time depth recorder and Fastloc GPS tag (model MK10AF, Wildlife Computers, www.wildlifecomputers.com), and (3) a VHF tag (164-165 MHz, Advanced Telemetry Systems; www. atstrack.com) used for locating the instrument packs after they had been shed by the harbor seals. All 3 instruments were consolidated in a single floatation pack, which were attached to the seals along the dorsal mid-line, on the anterior portion of the back. The GPS receivers were programmed to transmit ARGOS and GPS data and to store Fastloc GPS locations in the tag. In 2014, the Fastloc sampling interval was 30 min, so there were a maximum of 48 possible locations per day, although the actual number was much lower because the tags were programmed to a maximum of 4 failed transmissions (which occurs when the tag is underwater) per hour to conserve battery life (see Berejikian et al. 2016). Transmissions were also suppressed during haul-outs (i.e. when the pack was dry). In 2016, the maximum number of locations was increased to $144 \mathrm{~d}^{-1}$ and there was no limit on failed attempts. These changes resulted in a greater number of positions in 2016 than in 2014, but did not affect the capacity to detect steelhead (i.e. the steelhead tags were identically sized and configured and the same VMT hydrophones were used in both years). Stored data were downloaded from recovered VMTs (11 in 2014 and 15 in 2016, Table S1). To conserve battery life and ensure that transmissions would continue after the packs had separated from the seals, GPS data were only recorded once per week beginning on 1 July 2014 and 1 August 2016. Steelhead smolts complete their early migration through Puget Sound sometime in June (Moore et al. 2015). In both years, we used only Fastloc GPS positions that incorporated data from 5 or more satellites to minimize error (Hazel 2009). We determined GPS locations by analyzing archival GPS data from each tag using proprietary software from the manufacturer.

\subsection{Data analyses}

2.6.1. Survival estimation and migration behavior of steelhead

Cormack-Jolly-Seber (CJS) mark-recapture models (Cormack 1964, Jolly 1965, Seber 1965), implemented in the package 'RMark' (Laake 2013) in R version 
3.6.2 ( $\mathrm{R}$ Core Team 2019), were used to estimate the probability of detection $(p)$ at each sub-array and the probability of smolt survival $(\varphi)$ through each migration segment for 2014-2019. Nisqually steelhead smolt survival probabilities from 2006 to 2009 were estimated using previously published analogous CJS models (Moore et al. 2015). Segments included release (REL) to river mouth (RM), RM to NAR, NAR to CPS, CPS to ADM, and ADM to the western portion of JDF (Fig. 1). In 2018, detections were not available for NAR, CPS, or ADM, but we were still able to estimate RM-JDF survival probability. The modeling approach and survival estimation followed Moore et al. (2015). Briefly, a set of 36 models was constructed to test for interactions between year and segment-specific $\varphi$, additive effects of year, length, and release week on segment-specific $\varphi$, and an interaction (year $\times$ segment) and additive effect of year on $p$. A value of 0.685 was fixed for $p$ at JDF according to linear regression estimation methods detailed by Melnychuk (2009). Model goodness-of-fit parameters were satisfactory (Fletcher's c-hat < 1.2; Fletcher 2012).

Segment-specific survival values (i.e. $\varphi_{\mathrm{RM}-\mathrm{NAR}}, \varphi_{\mathrm{NAR}}$ ${ }_{\mathrm{CPS}}, \varphi_{\mathrm{CPS}-\mathrm{ADM}}$, and $\left.\varphi_{\mathrm{ADM}-\mathrm{JDF}}\right)$ from the model with the most support (i.e. lowest Akaike's information criterion corrected for small sample size, AICc) were multiplied to produce RM-JDF survival estimates for each year from 2014 to 2019, and error was calculated using the delta method. Each $\varphi_{\mathrm{RM}-\mathrm{JDF}}$ was converted to instantaneous mortality rate $(M)$ to increase normality and improve linearity of modeled relationships (Ricker 1975) as:

$$
M=-\ln (\varphi)
$$

Travel times were calculated for each tagged steelhead within a migration segment by subtracting the time of last detection at the first array from the time of first detection at the second array. Travel times were produced for each migration segment (RELRM, RM-NAR, NAR-CPS, CPS-ADM, ADM-JDF), and then averaged and summed to estimate total migration time. Marine migration was defined as RMJDF (i.e. excluded REL-RM). A linear model was used to determine whether average Puget Sound temperatures had an effect on RM-JDF travel time.

\subsubsection{Anchovy abundance index}

We used statistical models to describe annual larval and post-larval anchovy abundance (hereafter 'anchovy abundance') across Skagit Bay. The purpose of these models was to generate an abundance metric that was on the same time scale as survival (i.e. annual) and robust to interactions between fish phenology and minor variation in sampling intensity across months within years, minor variation in sampling intensity among tows, zero inflation (i.e. many observations of zero individuals), and right-skewed count data, which are typical of fish-monitoring data, including ours. We used a hurdle model approach, which separately modeled fish presence and fish abundance when present to quantify fish abundance. We modeled fish presence $\pi$ and counts when present $\mu$ from net tow $i$ in year $t$, month $m$, and volume filtered $w$ as:

$$
\begin{aligned}
& \operatorname{logit}\left(\pi_{i, t, m, w}\right)=\lambda_{t} X+\mathrm{f}_{1}(m)+w \\
& \operatorname{logit}\left(\mu_{i, t, m, w}\right)=\beta_{t} X+\mathrm{f}_{2}(m)+w
\end{aligned}
$$

where the former is fit using a binomial error distribution, the latter is fit using a zero-truncated negative binomial error distribution, $f($.$) represents a$ second-order random walk used to parameterize a nonlinear function that accounts for phenology, and $X$ is a binary variable describing whether an observation did (1) or did not (0) occur during a particular year $t$. There are no global intercepts so that year effects $\left(\lambda_{t}\right.$ and $\left.\beta_{t}\right)$ capture interannual differences in fish abundance. The anchovy abundance index $A$ in year $t$ is the product of anchovy probability of presence and anchovy counts when present for each year $t$ :

$$
A_{t}=\operatorname{logit}^{-1}\left(\lambda_{t}\right) \mathrm{e}^{\beta_{t}}
$$

In plain terms, this model asks how many fish we expect to catch per tow in year $t$, filtering out effects of seasonality in fish abundance, and accounting for zero-inflated, right-skewed fish counts and the expectation of greater fish counts when nets filter more water volume (raw counts compared to abundance indices: Fig. 3).

Models were fit in the R package 'INLA' (Rue et al. 2009, Lindgren \& Rue 2015).

\subsubsection{Relationships among environmental variables and steelhead mortality}

We tested support for the overall hypothesis that increased water temperatures associated with the marine heat wave improved conditions for anchovy, reduced predation pressure on steelhead, and reduced steelhead mortality. To do so, we constructed 6 models to assess the strength of relationships between (1) Puget Sound temperatures and steelhead mortality (Models 1 and 2), (2) anchovy abundance 

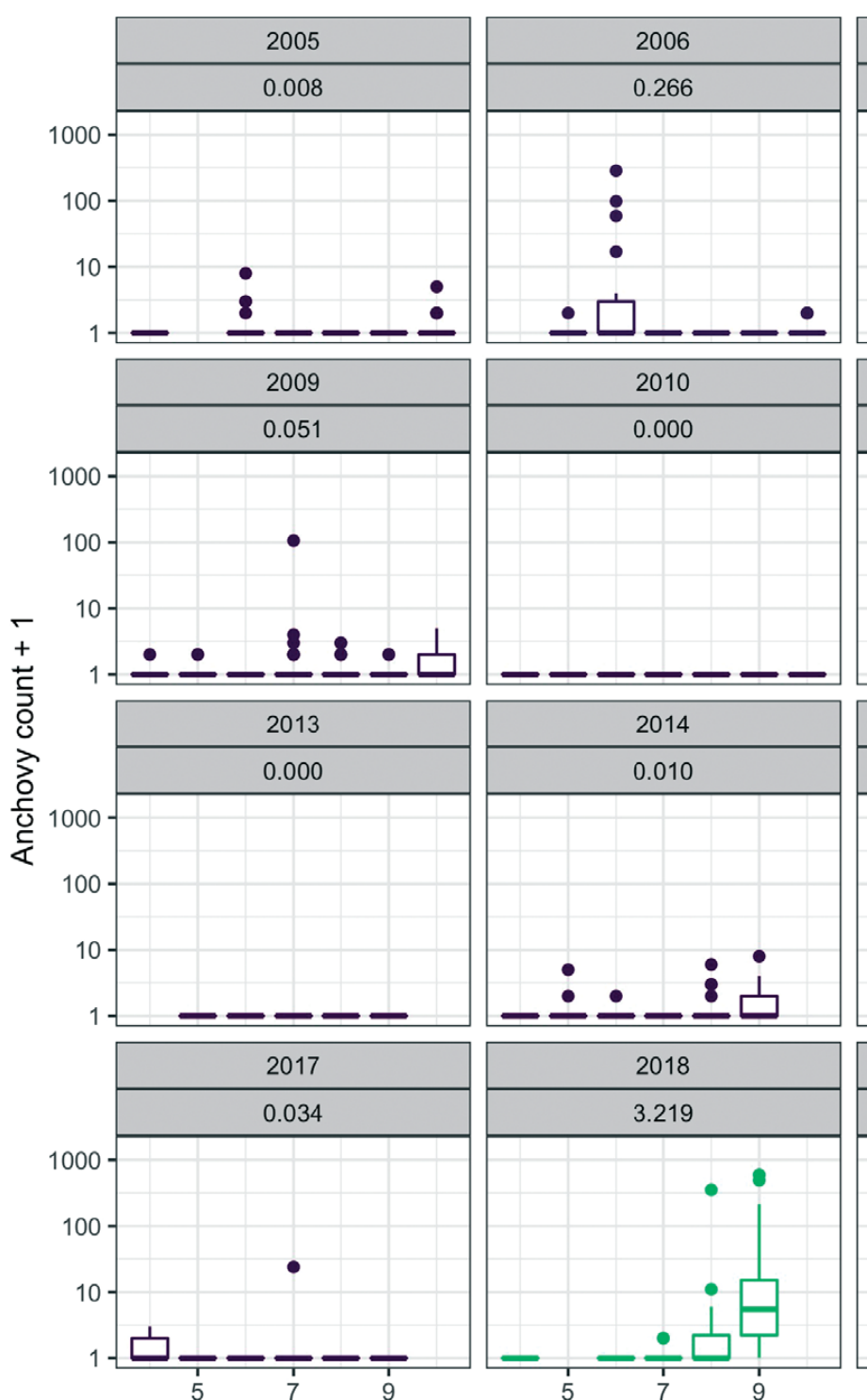
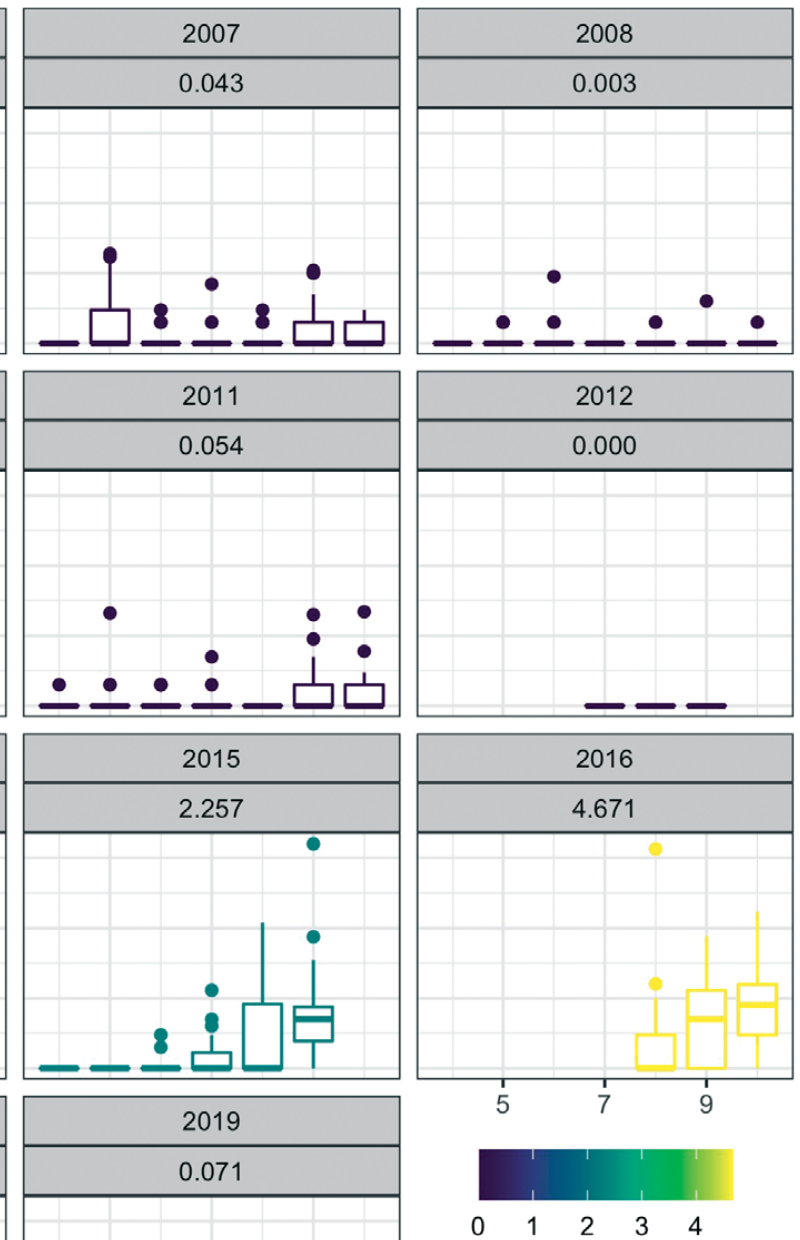

Anchovy abundance index

Fig. 3. Raw counts of anchovy across years and months compared to annual abundance indices. Numbers at the top of the panel and colors correspond to anchovy abundance index. In the boxplots: upper and lower hinges: first and third quartiles; mid-line: median; whiskers: points within $1.5 \times$ interquartile range; dots represent data outside of $1.5 \times$ interquartile range

index and Puget Sound temperature and PDO (Models 3 and 4), and (3) anchovy abundance index and steelhead mortality (Models 5 and 6), then compared pairs of models to understand mechanisms. Lastly, we compared evidence of predation by harbor seals in 2 years representing the highest (2014) and lowest (2016) estimates of steelhead mortality.

To determine whether temperature during or prior to migration might affect observed steelhead mortality patterns, we modeled instantaneous steelhead mortality $(M)$ in each year $(t)$ as a linear function of the Puget Sound temperature (PST) during the year prior to migration (Model 1) and $M$ as a function of
PST in the year of migration (Model 2) using the base function ' $\mathrm{lm}$ ' in R version 3.6.2 (R Core Team 2019). We used PST rather than PDO to assess the strength of these relationships, because mortality was estimated within Puget Sound, and because the 2 temperature indices were highly correlated (Fig. 2). The annual mean PST for the entire year preceding steelhead migration $(t-1)$ was calculated to test for 'preconditioning' effects (i.e. temperature influences on larval and post-larval anchovy). The annual mean PST during the year of migration $(t)$ was calculated for the 6 mo preceding and including the migration period (January to June): 
(Model 1)

$$
M_{t}=\beta_{0}+\beta_{1} \mathrm{PST}_{t-1}
$$

(Model 2)

$$
M_{t}=\beta_{0}+\beta_{1} \mathrm{PST}_{t}
$$

We then tested the hypothesis that annual anchovy abundance in Puget Sound is temperature-dependent. Abundance of anchovy could be the consequence of processes within Puget Sound or at larger spatial scales due to transport of larvae produced offshore, so we examined 2 temperature-dependent models. First, we fit the natural log of the anchovy abundance index $(A)$ as a function of the annual mean PST (Model 3). To evaluate whether anchovy contribution to Puget Sound was more likely to have resulted from resident anchovies or offshore reproduction, we compared the relationship established in model 3 with that between anchovy abundance and the monthly PDO (Model 4) mean (across all $12 \mathrm{mo}$ ):

(Model 3)

$$
\begin{aligned}
& \ln A_{t}=\beta_{0}+\beta_{1} \mathrm{PST}_{t} \\
& \ln A_{t}=\beta_{0}+\beta_{1} \mathrm{PDO}_{t}
\end{aligned}
$$

(Model 4)

Anchovy abundance in the year prior to steelhead migration $(t-1)$ may predict age-1 anchovy abundance during the year of migration, when anchovies are of a size (90-125 mm; Litz et al. 2008) large enough to attract predators that also prey on steelhead smolts. We tested support for the hypothesis that steelhead mortality rate in year $t$ was negatively correlated with anchovy abundance in the year prior to migration ( $t-1$; Model 5):

(Model 5)

$$
M_{t}=\beta_{0}+\beta_{1} \ln A_{t-1}
$$

Lastly we compared the fit of Model 5 to the relationship between steelhead mortality rate and anchovy abundance in the year of migration (Model 6). Steelhead mortality in year $t$ was predicted to be less strongly correlated with post-larval anchovy abundance in year $t$, because post-larval anchovies are unlikely prey for predators of steelhead.

$$
\text { (Model 6) } \quad M_{t}=\beta_{0}+\beta_{1} \ln A_{t}
$$

We compared support for each pair of models (Models 1 and 2, Models 3 and 4, Models 5 and 6) with support for the null model using AICc in the package 'MuMIn' for R (Barton 2020). A second set of parallel models was constructed to test for effects of the same variables using a CJS framework (Text S1 in the Supplement).

\subsubsection{Predation by harbor seals}

Consumption of tagged steelhead by harbor seals in 2014 was determined using several criteria described by Berejikian et al. (2016). All steelhead tags detected by seal-mounted VMT in 2016 were subjected to the same criteria to determine whether any 2016 tags were consumed by harbor seals. Seal consumption (hereafter 'haulout mortality') of tagged steelhead smolts was quantified at 3 haulout locations (Colvos Rocks, Orchard Rocks, and Blakely Rocks; Fig. 1) in Puget Sound based on repeated tag detections by seal-mounted VMTs near the haulouts, plus at least one of the following: (1) detection patterns on tidal or temporal cycles indicative of harbor seal movements and never detected further along the migration path, (2) tag subsequently detected stationary after the smolt outmigration period, (3) no evidence that tags were later detected migrating to the ocean (see Berejikian et al. 2016 for further details). Additional interactions between seal-mounted VMTs and tagged steelhead quantified throughout the study area included 'survivors' and 'stationary tags'. A tagged steelhead was categorized as a survivor when it was detected at least once on a seal-mounted VMT and then subsequently detected on a receiver array further along the migration path. We defined a tag as stationary when it had more than 1 detection (separated by at least $24 \mathrm{~h}$ ) by a seal-mounted VMT at the same location. Haulout mortalities, survivors, and stationary tags only within the area covered by the range of instrumented seals in both 2014 and 2016 (within Puget Sound, between latitudes $47^{\circ} 27^{\prime} 0^{\prime \prime} \mathrm{N}$ and $48^{\circ} 0^{\prime} 0^{\prime \prime} \mathrm{N}$; Fig. 1) were included in the annual comparison. Segment-specific survival probabilities (see Section 2.6.1) were used to determine the number of smolts remaining at the end of each segment by multiplying the survival rate by the number of fish entering the specific segment.

\section{RESULTS}

\subsection{Early marine survival and behavior of steelhead}

Nisqually steelhead smolt RM-JDF survival probability ranged from 0.06 in 2014 to 0.38 in 2016 and 2017. 2015 was the first year in which survival probabilities exceeded estimates during the earlier 20062009 time period (range $=0.05-0.13$ ) (Fig. 4). Survival probabilities decreased to 0.24 in 2018 and 0.19 in 2019 (Fig. 4). The CJS model with the lowest AICc included only a segment $\times$ year effect on $\varphi$, indicating support for unique estimates for each migration segment within each year, and an additive effect of year on $p(\triangle \mathrm{AICc}=2.06$ over second best model, weight $=0.49$ ). 


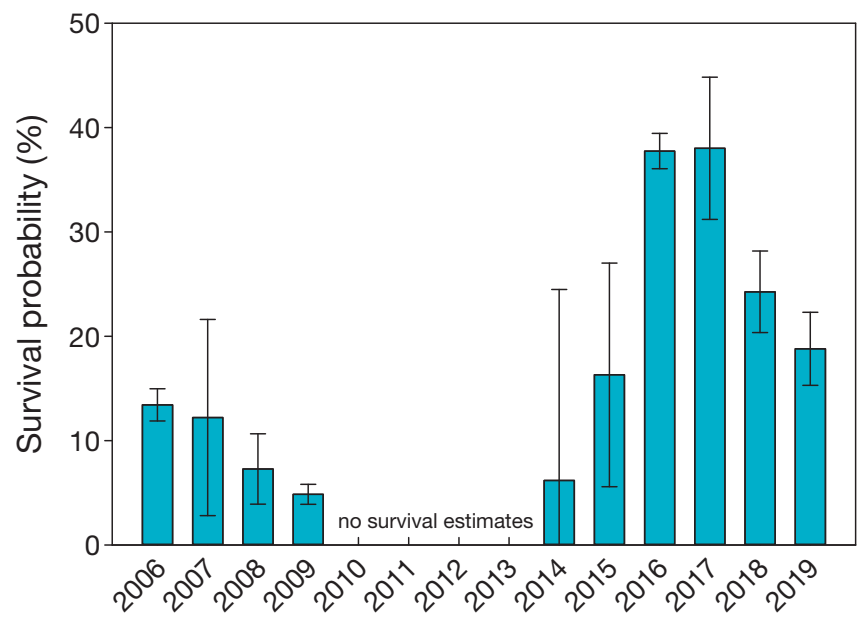

Fig. 4. Steelhead survival probability estimates $( \pm \mathrm{SE})$ from river mouth to the Strait of Juan de Fuca derived from markrecapture models using acoustic telemetry detection data. Survival probabilities from 2014-2019 estimated in this study were combined with previously published early marine survival probabilities from the same Nisqually River steelhead population (Moore et al. 2015)

In most years, steelhead REL-RM and RM-NAR survival probabilities were similar; the lowest RELRM survival was estimated in 2016 (Table 2). In 2014, steelhead survival probability through central and north Puget Sound (NAR-CPS and CPS-ADM) was much lower than survival probability through the same segments in 2015-2017. Interannual variability in survival from ADM to JDF was lower than through segments in the main basin of Puget Sound (NARCPS and CPS-ADM; Table 2).

Travel times through the entire Puget Sound migration (RM-JDF) ranged from $8.6 \mathrm{~d}$ in 2015 to $12.1 \mathrm{~d}$ in 2017 (Fig. 5). Nearly indistinguishable segmentspecific travel rates were observed between the years of lowest (2014) and one of the highest (2016) steelhead RM-JDF survival (Fig. 5), indicating that differences in neither time exposed to Puget Sound

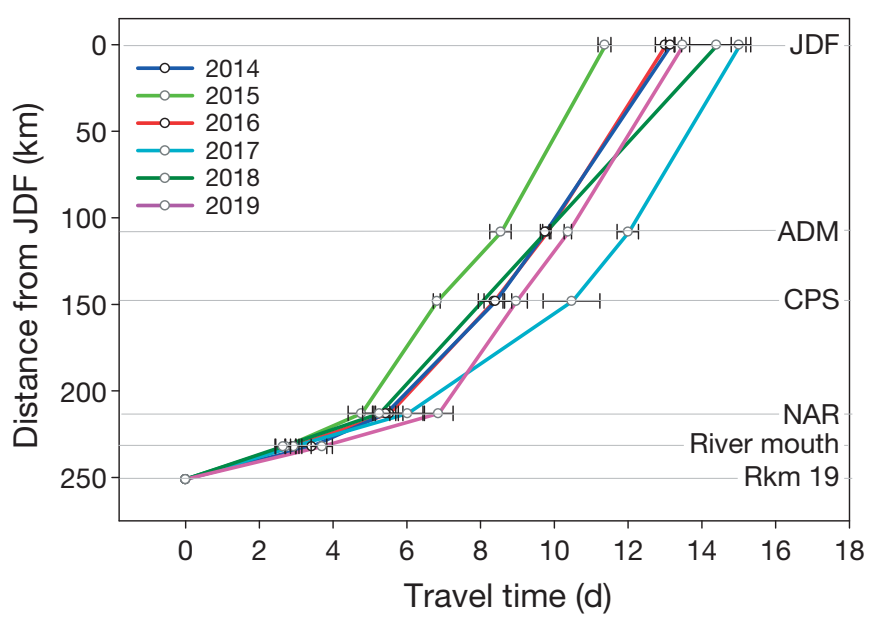

Fig. 5. Average annual travel time $( \pm \mathrm{SE})$ between release at river kilometer (Rkm 19) and the river mouth (RM), RM and the Tacoma Narrows (NAR), NAR and Central Puget Sound (CPS), CPS and Admiralty Inlet (ADM), and ADM and the Strait of Juan de Fuca array (JDF), plotted by distance of each array to JDF

conditions nor migration behavior explain interannual differences in survival. Also, travel time was not correlated with April-June average PST $(\mathrm{r}=-0.48$, $\mathrm{df}=6, \mathrm{p}=0.23$ ).

\subsection{PST and associated anchovy abundance increase}

The instantaneous mortality rate of steelhead in Puget Sound was negatively related to annual mean PST during the year prior to migration (Model $1, \mathrm{r}^{2}=$ $0.75, p=0.001$, Fig. 6a). The 2 years of lowest steelhead mortality rates (2016 and 2017) were preceded by the 2 warmest years in the dataset $(2015$ and 2016). January-June PST in the year of migration was only weakly and negatively related to steelhead mortality rate (Model 2, $\mathrm{r}^{2}=0.31, \mathrm{p}=0.09$; Fig. 6b), and did not predict steelhead mortality patterns as

Table 2. Segment-specific estimates of Nisqually steelhead smolt survival probability $(\varphi) \pm$ SE for release (REL) to river mouth (RM), RM to Tacoma Narrows (NAR), NAR to central Puget Sound (CPS), CPS to Admiralty Inlet (ADM), and ADM to the Strait of Juan de Fuca (JDF) from 2014 to 2019. -: Detection data from NAR, CPS, and ADM were unavailable in 2018. Segmentspecific estimates from mark-recapture models using 2006-2009 detection data are published in Moore et al. (2015)

\begin{tabular}{|cccccrr|}
\hline Year & REL-RM & RM-NAR & NAR-CPS & CPS-ADM & ADM-JDF & RM-JDF \\
\hline 2014 & $0.94 \pm 0.02$ & $0.59 \pm 0.07$ & $0.45 \pm 0.09$ & $0.26 \pm 0.10$ & $0.87 \pm 0.31$ & $0.06 \pm 0.18$ \\
2015 & $0.90 \pm 0.03$ & $0.60 \pm 0.06$ & $0.85 \pm 0.09$ & $0.74 \pm 0.12$ & $0.43 \pm 0.13$ & $0.16 \pm 0.11$ \\
2016 & $0.70 \pm 0.04$ & $0.71 \pm 0.05$ & $0.83 \pm 0.05$ & $0.82 \pm 0.07$ & $0.78 \pm 0.11$ & $0.38 \pm 0.02$ \\
2017 & $0.90 \pm 0.03$ & $0.65 \pm 0.05$ & $0.77 \pm 0.06$ & $0.85 \pm 0.06$ & $0.90 \pm 0.12$ & $0.38 \pm 0.07$ \\
2018 & $0.92 \pm 0.02$ & - & - & - & - & $0.24 \pm 0.04$ \\
2019 & $0.93 \pm 0.02$ & $0.69 \pm 0.04$ & $0.54 \pm 0.05$ & $0.70 \pm 0.07$ & $0.71 \pm 0.11$ & $0.19 \pm 0.04$ \\
\hline
\end{tabular}




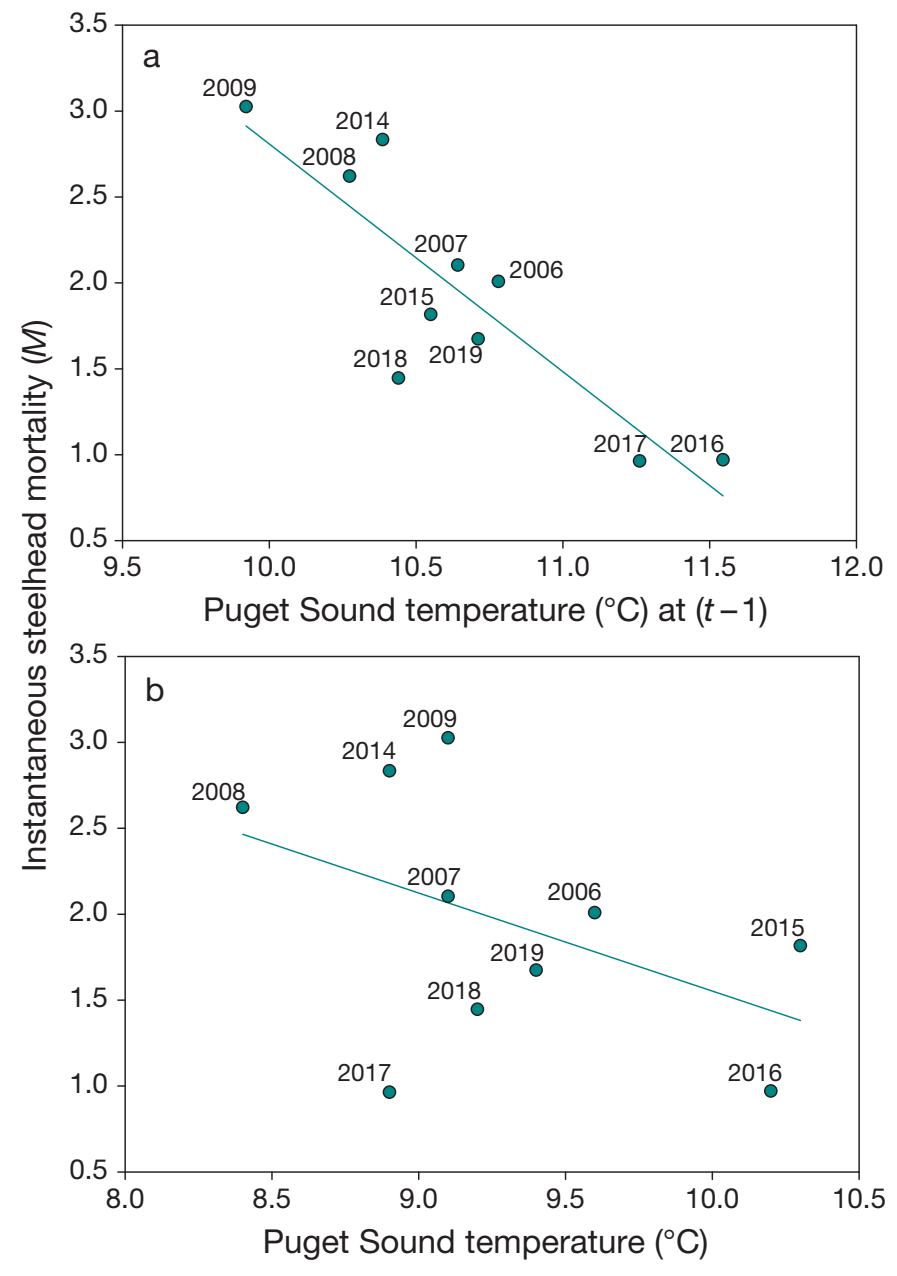

Fig. 6. (a) Steelhead mortality rate is strongly related to annual mean Puget Sound temperatures during the year before migration $\left(r^{2}=0.75, p=0.001\right)$. (b) Mean of JanuaryJune Puget Sound temperatures are also negatively related to steelhead mortality rate, although the relationship is weaker $\left(r^{2}=0.31, p=0.09\right)$. Lines represent the linear fit of Model 1 (a) and Model 2 (b)

well as PST in the year prior to migration (Table 3, Model comparison A; Table S2 in the Supplement).

Anchovy abundance was positively related to PST (Model 3, $r^{2}=0.67, p=0.004 ;$ Fig. 7a). Two of 3 years of highest anchovy abundance coincided with annual mean PST exceeding $11.0^{\circ} \mathrm{C}$, which only occurred in 2015 and 2016 within our time series (Fig. 7a). Anchovy abundance was also positively related to the PDO (Model 4, $\mathrm{r}^{2}=0.36, \mathrm{p}=0.07$; Fig. 7b), as expected given the strong correlation between PDO and PST (Fig. 2), although the relationship was not as strong as that between anchovy abundance and PST (Table 3, model comparison B; Table S2).

Steelhead mortality rate was negatively related to anchovy abundance during the year prior to migra-
Table 3. Results of Akaike's information criterion corrected for small sample size (AICc) model comparison analysis to understand: (A) whether average Puget Sound temperature (PST) during the year prior to migration $(t-1)$ is a strong predictor of steelhead mortality $(M)$ relative to average PST during the year of migration $(t)$, (B) the relative strength of annual average PST as a predictor of anchovy abundance $(A)$ in Puget Sound compared to the strength of annual PDO indices, and (C) whether anchovy abundance during the year prior to migration is better than anchovy abundance in the year of migration as an indicator of steelhead mortality

\begin{tabular}{|lccccc|}
\hline $\begin{array}{l}\text { Model } \\
\text { comparison }\end{array}$ & $\begin{array}{c}\text { Model } \\
\text { number }\end{array}$ & Model & AICc & AAICc & Weight \\
\hline A & 1 & $M_{t}=$ PST $_{t-1}$ & 17.1 & 0.00 & 0.984 \\
& Null $_{1,2}$ & $M_{t}=1$ & 26.5 & 9.39 & 0.009 \\
B & 2 & $M_{t}=\mathrm{PST}_{t}$ & 27.1 & 9.94 & 0.007 \\
& 3 & $\ln A=\mathrm{PST}_{t}$ & 44.9 & 0.00 & 0.924 \\
C & 4 & $\ln A=\mathrm{PDO}_{t}$ & 50.9 & 6.09 & 0.044 \\
& Null $_{3,4}$ & $\ln A=1$ & 51.6 & 6.71 & 0.033 \\
& 5 & $M_{t}=A_{t-1}$ & 23.2 & 0.00 & 0.710 \\
& 6 & $M_{t}=A_{t}$ & 26.2 & 3.00 & 0.158 \\
& Null $_{5,6}$ & $M_{t}=1$ & 26.5 & 3.37 & 0.132 \\
\hline
\end{tabular}

tion (Model 5, $\mathrm{r}^{2}=0.57, \mathrm{p}=0.01$, Fig. 8a), indicating that high projected abundance of age-1 anchovy contributed to reduced mortality of migrating steelhead. The relationship between steelhead mortality and anchovy abundance in the year of migration was not as strong (Model 6, $\mathrm{r}^{2}=0.37, \mathrm{p}=0.06$; Fig. 8b, Table 3, model comparison $\mathrm{C}_{\boldsymbol{i}}$ Table S2).

\subsection{Harbor seal predation}

Evidence of harbor seal predation on steelhead was substantial in 2014, when steelhead survival rates were lowest, whereas we observed little evidence of harbor seal predation in 2016, when steelhead survival was highest (Fig. 4). In 2014, 6 haulout mortalities $(17 \%$ of tagged steelhead surviving to CPS) were detected at CPS haulout sites (Orchard and Blakely Rocks) and 1 (10\% of tagged steelhead surviving to ADM) in north Puget Sound (Colvos Rocks; Fig. 9a). In 2016, no mortality events were observed at CPS harbor seal haulouts, and 1 mortality ( $2 \%$ of tagged steelhead surviving to ADM) was recorded at the north Puget Sound haulout (Fig. 9b). The percentage of available smolts consumed by harbor seals reflects only those predation events identified at the monitored haulouts, so represents a minimum percentage and is not a predation rate. Additional harbor seal predation may have occurred throughout other areas of Puget Sound (see Fig. 1 for additional locations of major haulouts). Not included 


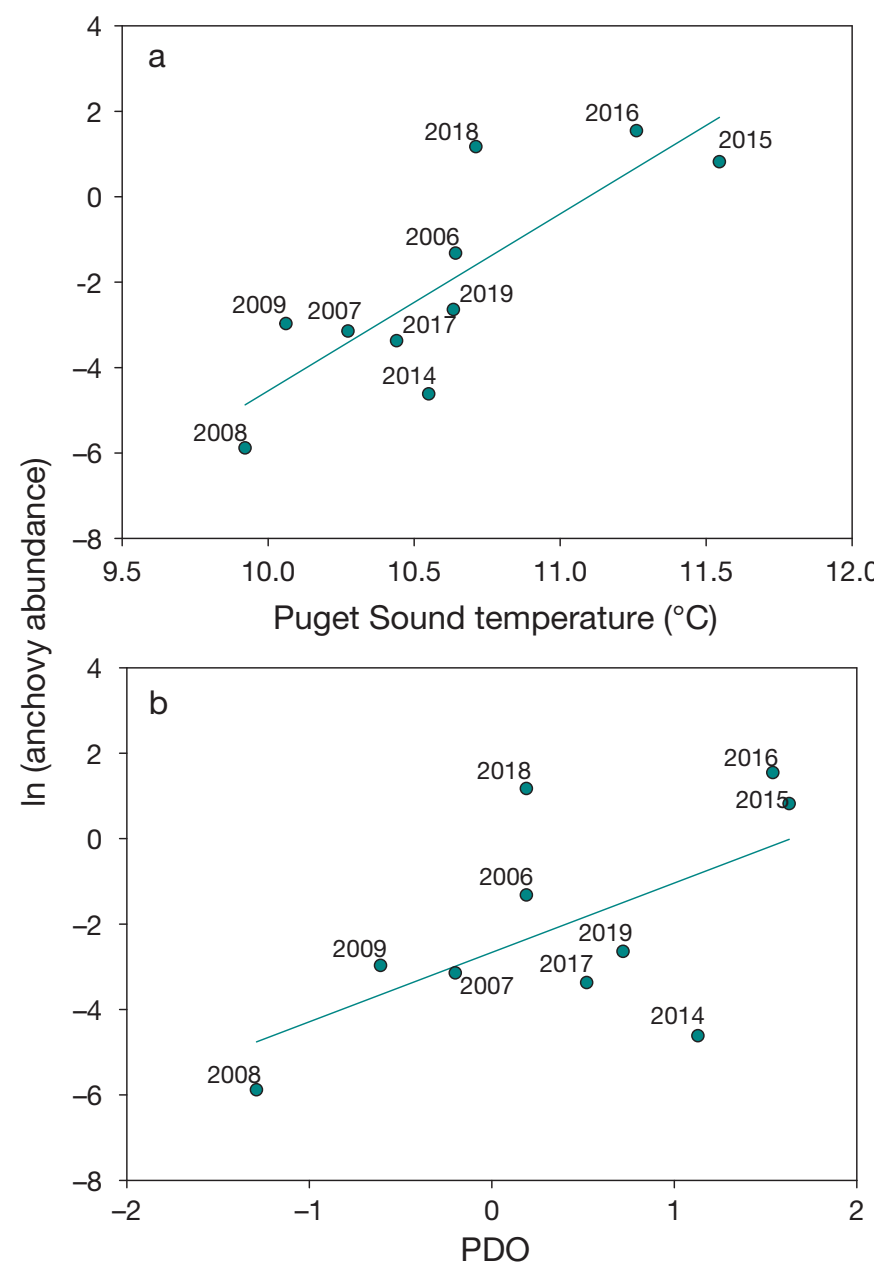

Fig. 7. (a) Anchovy abundance increases with increasing annual mean Puget Sound temperatures $\left(r^{2}=0.67, p=0.004\right)$, a stronger positive relationship than (b) the increase in anchovy occurrence related to annual mean Pacific Decadal Oscillation (PDO) $\left(\mathrm{r}^{2}=0.36, \mathrm{p}=0.07\right)$. Lines represent the linear fit of Model 3 (a) and Model 4 (b)

in the percentages were 3 additional stationary tags observed in 2014 within close proximity (2 within $4 \mathrm{~km}$ and 1 within $8 \mathrm{~km}$ ) to 1 of the monitored haulouts that represent possible additional harbor seal predation events. No stationary tags were located near monitored haulouts in 2016. Spatial coverage of instrumented harbor seals did not differ substantially between years and therefore could not account for the difference in recorded mortality events (Fig. 9).

\section{DISCUSSION}

Steelhead smolt mortality through Puget Sound varied substantially from 2006 to 2019 and decreased in response to the marine heatwave that affected the North Pacific Ocean and Puget Sound beginning in
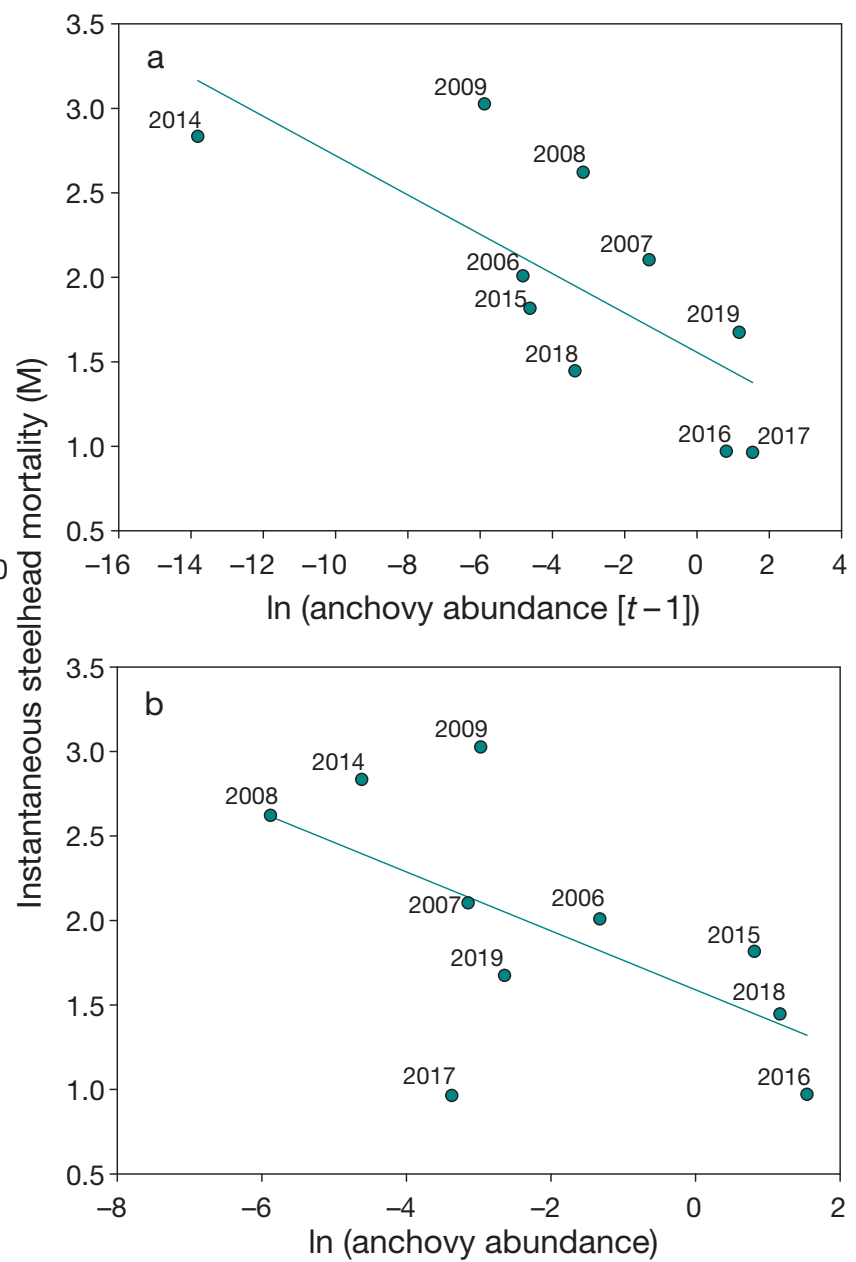

Fig. 8. (a) Steelhead mortality rate decreases with increases in anchovy abundance in the year prior to migration $\left(\mathrm{r}^{2}=\right.$ $0.57, \mathrm{p}=0.01$ ), a stronger relationship than (b) the relationship between steelhead mortality and anchovy occurrence in the same year $\left(r^{2}=0.37, p=0.06\right)$. Lines represent the linear fit of Model 5 (a) and Model 6 (b)

late 2014 and continuing through 2016. During the years of this study, variability in steelhead smolt mortality was strongly correlated with PST in the year prior to migration, and less so with annual mean temperatures averaged over the months preceding migration. The relationship between anchovy and PST provides one possible mechanism by which steelhead benefit from increased water temperatures during the year prior to migration. Warmer temperatures appear to favor anchovy abundance in the Salish Sea and northern California Current (Leising et al. 2015, Auth et al. 2018, Duguid et al. 2019), and temperature was correlated with larval anchovy abundance in Puget Sound. Anchovies can be an important prey item for harbor seals (Lance et al. 2012), including in Puget Sound during the timeframe of our study (Thomas et al. in press), and are likely exploited by 

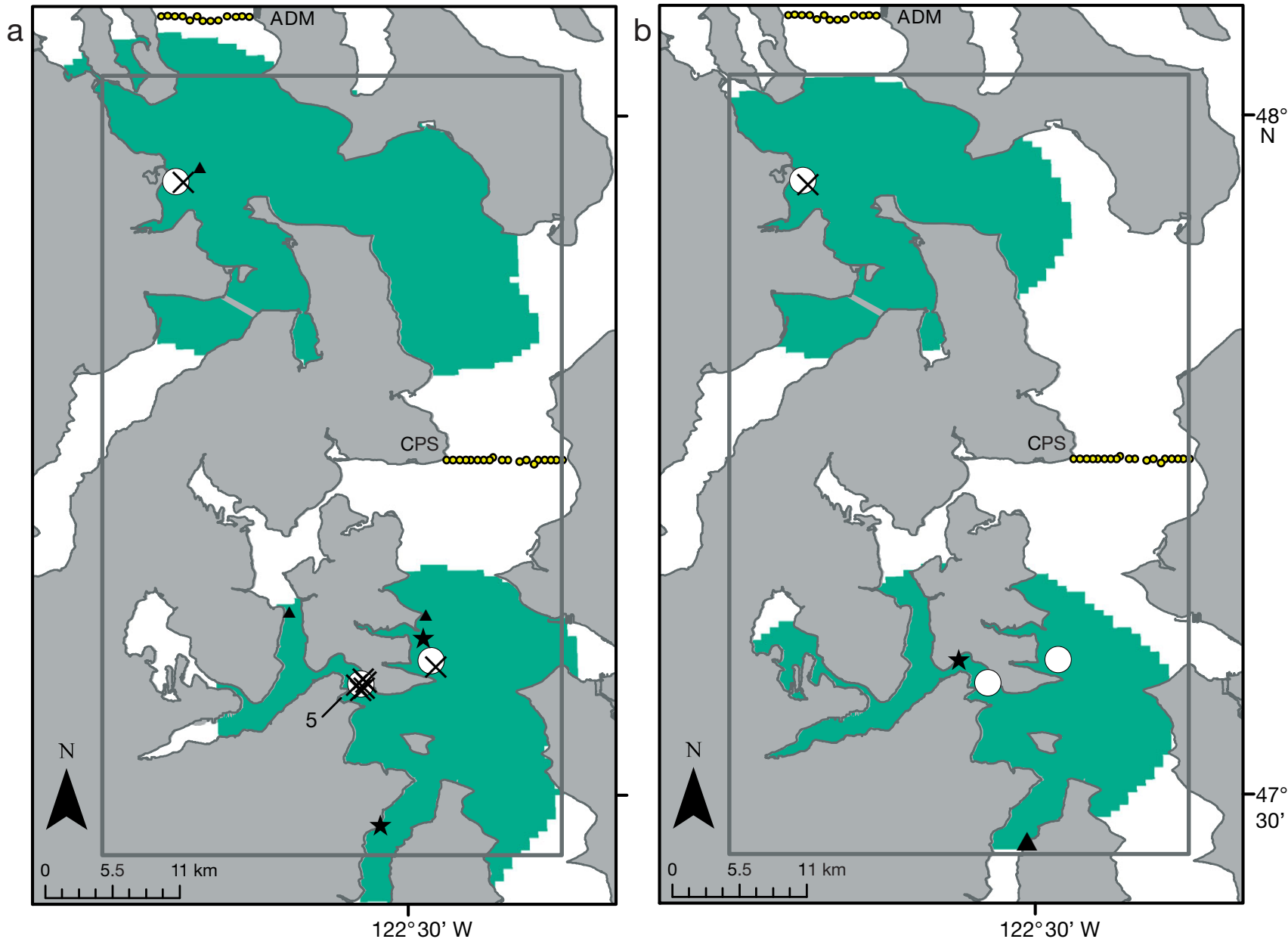

Fig. 9. Tagged harbor seal GPS fastloc location range in (a) 2014 and (b) 2016. Green shading represents areas where positions of instrumented seals were recorded more than 2 times per $\mathrm{km}^{2}$. Steelhead mortalities at haulouts (black $\times \mathrm{s}$ within circles), steelhead mortalities away from haulouts $(\boldsymbol{\Delta})$, and steelhead survivors detected by harbor seals $(\star)$, were quantified using detection patterns recorded on harbor seal VMTs and fixed arrays (o; see Section 2), only within 2014 and 2016 coverage areas (i.e. areas with location densities $>2 \mathrm{~km}^{-2}$ ) that completely overlapped (gray box). ADM: Admiralty Inlet; CPS: Central Puget Sound

other opportunistic predators in the Salish Sea. We hypothesize that the large anchovy pulse that occurred during the marine heatwave provided a substantial alternative prey resource, lessening the predation pressure on steelhead smolts. Between 62 and $94 \%$ of steelhead smolts died each year (see Table 2 ) during the 8-12 d migration, suggesting that predation was the most likely cause of mortality. Other potential sources of mortality such as disease, starvation, or contaminants, would be more likely to cause mortality over longer time periods than steelhead smolts were present in Puget Sound (Puget Sound Steelhead Marine Survival Workgroup 2018). Similar travel times among years provide an indication that steelhead behavior does not explain interannual variation in survival rates.

The greatest contrast in steelhead survival rates occurred between 2014 (lowest estimate) and 2016 (highest estimate). During these 2 years, evidence of harbor seal predation on steelhead was greater during 2014 and lower during 2016, suggesting that predation pressure on steelhead was somewhat alleviated during a year of peak anchovy abundance. Other opportunistic predator species may have similarly shifted feeding to atypically abundant anchovy, further alleviating predation pressure on migrating steelhead. The high mortality rates experienced by Nisqually River steelhead from 2006 to 2009 and in 2014 corresponded to similarly high mortality rates observed in several other steelhead populations in Puget Sound (Moore et al. 2015) and in the Strait of Georgia (Melnychuk et al. 2014). Predation was identified as a major cause of high steelhead mortality in Puget Sound (Berejikian et al. 2016, Moore \& Berejikian 2017) and speculated as such in other areas within the Strait of Georgia (Balfry et al. 2011, Melnychuk et al. 2013). 
Warm ocean temperatures contributed to major changes in species distribution and abundance, resulting in what appears to be shifting predation pressure that ultimately reduced mortality of steelhead. Elsewhere, similar complex ecological interactions have been shown to influence marine survival rates, and have the potential to substantially impact the productivity and likelihood of recovery of depressed salmonid populations. For example, Wells et al. (2017) documented how oceanographic conditions mediated common murre Uria aalge predation on Chinook salmon Oncorhynchus tshawytscha outmigrants when low preferred prey (rockfish Sebastes spp.) availability caused murres to shift predation pressure to anchovy aggregations that overlapped with Chinook ocean entry locations. Additionally, decreased survival of Atlantic salmon Salmo salar was attributed to shifts in ocean temperatures as cod predators occupied new northern habitats that overlapped with salmon smolt migration corridors (Friedland et al. 2017). Increased variability in ocean climate patterns is leading animal distribution and phenology to shift in response (Sydeman et al. 2013, Munsch et al. 2019), changing the ecological dynamics controlling salmon marine survival, and placing new emphasis on understanding biological-physical links.

Anchovy are native to the Salish Sea ecosystem, although occurrence has typically been somewhat rare in recent years, prior to the marine heat wave (Greene et al. 2015). In 2015 and 2016, however, widespread reports of large numbers of anchovies throughout the Salish Sea prompted a historical analysis of anchovy abundance trends by Duguid et al. (2019). These authors used qualitative and quantitative data from 1940 to 2016 to describe the episodic nature of anchovy fluctuations in the Salish Sea and the tendency of anchovy abundance to respond positively to warm Salish Sea and Pacific Ocean temperatures. Along the US West Coast, Brodeur et al. (1985) documented high abundance of anchovies associated with warm, low-salinity waters of the strong $1983 \mathrm{El}$ Niño event. Similarly, abundant anchovies coincided with anomalous ocean conditions in the northern California Current ecosystem in 2005 (Brodeur et al. 2006) and during the recent marine heat wave (Auth et al. 2018). Not all reported relationships between anchovy productivity and temperature are positive (see Chavez et al. 2003 and Lindegren et al. 2013), but the relationship may depend on latitude of the considered subpopulation. The Salish Sea is located near the northern limit of the northern subpopulation range (northern California to British Columbia) and may limit anchovy productivity, in contrast to warmer environments inhabited by the central and southern subpopulations (Baja California to San Francisco) that provide a different range of thermal conditions. Cooler northern waters may limit anchovy recruitment processes or inhibit overwinter survival in most years, such that in very warm years, anchovy may be capable of range expansion and increases in reproductive success or larval survival in northern areas.

PST was a slightly better indicator of anchovy occurrence in Puget Sound than PDO, suggesting that Puget Sound anchovies were spawned from resident populations and were responding to local rather than oceanic conditions. Some spawning within Puget Sound was evident in the consistent larval anchovy catches in the Skagit tow-nets throughout spring and summer months. Lengths of larval anchovies caught in August and September of 2018 were as small as 22 and $26 \mathrm{~mm}$, respectively (C. Greene unpubl. data). It remains unclear whether apparent increases in anchovy abundance result from protracted or more successful resident anchovy spawning under warmer conditions, or a combination of resident spawning and transport of larvae or eggs from the North Pacific Ocean. Increases in mean monthly PSTs above $11^{\circ} \mathrm{C}$ coincided with increased anchovy abundance in Puget Sound, and patterns in the annual anchovy abundance data show very low levels in years with cooler average temperatures. This observation is supported by empirical studies showing a distinct increase in the percentage of normal larval development and survival of anchovy exposed to temperatures warmer than $11^{\circ} \mathrm{C}$ relative to groups reared in $10.5^{\circ} \mathrm{C}$ or cooler water (Brewer 1976). Larval anchovy densities off the US West Coast were anomalously high during the 2014-2016 marine heat wave due to both expanded distribution and prolonged spawning (Auth et al. 2018), increasing the potential for transport into the Salish Sea. Both transport from offshore and production within Puget Sound are plausible, although it appears that some level of resident spawning did take place during the years following the onset of the 2014-2016 marine heat wave.

Mid-trophic level fish species, or 'forage fish', are subject to variability in physical ocean processes and can have a strong effect on marine ecosystem dynamics, because they are important prey for a variety of taxa (Rice 1995, Bakun 2006). Major declines in populations of some forage fish species (e.g. Pacific herring Clupea pallasii, Siple \& Francis 2016; surf smelt Hypomesus pretiosus, Greene et al. 2015) over the last 3 to 4 decades have coincided with significant increases in human population size and associated urbanization in the Puget Sound region. At the same 
time, harbor seal populations increased to apparent carrying capacity by 1999 (Jeffries et al. 2003). Reductions in forage fish abundance may have increased exposure of migrating steelhead to predation by pinnipeds and resulted in reduced marine survival rates over the past 3 decades (Kendall et al. 2017). Episodic increases in anchovy abundance during the 1980s (Duguid et al. 2019) associated with very high marine survival rates and abundances of Puget Sound steelhead (Kendall et al. 2017) suggest that anchovies may now provide a periodic source of alternative prey for harbor seals and other higher trophic level species, and reduce predation pressure on steelhead and possibly on other salmon.

Harbor seals are generalist predators that exploit seasonally and regionally available prey resources (Olesiuk 1993) and tend to target small, energy-rich fish species (Lance et al. 2012). Harbor seals are highly mobile, with core foraging radii of approximately $20 \mathrm{~km}$ (Peterson et al. 2012), but sometimes make long-distance trips away from core haulout areas to exploit seasonal prey resources (Brown \& Mate 1983, Lowry et al. 2001). Most harbor seal detections recorded in this study occurred within only a few kilometers of their capture site, although we did observe some individuals moving more extensively between Puget Sound regions, and even into Canada. Harbor seal mobility allows them to forage in a wide variety of habitats. Anchovies are present throughout marine habitats of the Salish Sea but are more likely encountered in nearshore, shallow waters of the Strait of Georgia (Duguid et al. 2019), whereas steelhead are more likely detected further away from shorelines in the surface waters of mid-Puget Sound channels (M. Moore unpubl. data). It is possible that harbor seals may have vacated habitat used by migrating steelhead to target large aggregations of anchovies.

The documented steelhead mortalities at harbor seal haulouts in 2014 suggest that harbor seals may constitute a substantial source of mortality under certain ecological conditions. Recent harbor seal diet analyses, combined with bioenergetic estimates, have provided increasing evidence that pinniped predation can account for substantial numbers of outmigrating juvenile salmon in the Salish Sea (Chasco et al. 2017, Thomas et al. 2017). The present study collected data from only a few monitored harbor seals at each of 3 most prominent harbor seal haulout areas along the steelhead migration corridor. We did not attempt to expand the number of detected predation events to account for non-monitored seals foraging in different areas or to represent other, smaller haulout areas throughout the rest of the study area. Thomas et al. (2017) found that juvenile steelhead co-occurred with other salmon in scat samples collected from Strait of Georgia haulouts and made up an average $2.5 \%$ of harbor seal diets based on DNA quantification techniques. Bioenergetics-based simulations of harbor seal predation effects on Puget Sound Chinook salmon demonstrate that a small diet fraction coupled with high predator abundance can translate into a large number of consumed outmigrating smolts (Chasco et al. 2017). Steelhead smolts are even less abundant than other Pacific salmon species and require higher marine survival rates than other salmon to maintain positive population growth rates. Thus, even a small percentage of steelhead in harbor seal diet may represent a significant limiting factor on steelhead productivity.

Changes in abundance or distribution of 2 other important species may have had significant ecological impacts over the course of this study. First, the West Coast Transient (marine mammal eating; i.e. not the endangered resident population) killer whale Orcinus orca population experienced growth in recent years, and visited the Salish Sea more frequently between 2011 and 2017 than during the previous 7 yr (Houghton et al. 2015, Shields et al. 2018). Transient killer whales have the potential to temporarily influence the behavior and distribution of marine mammals, and under some circumstances, have been estimated to consume substantial numbers of harbor seals (London 2006). However, transient-sightings data from Puget Sound (Olsen et. al 2019) indicate that the largest increase in transient visits occurred in 2015 and 2016, followed by marked decreases in 2017 and 2018. This pattern does not correspond with the steelhead survival patterns during that timeframe. Pacific hake Merluccius productus is a bentho-pelagic fish species and a favored prey resource for Salish Sea harbor seals (Thomas et al. in press). Hake abundance estimates from bottom trawl surveys consistently conducted in Puget Sound from 2008 to 2018 increased well above the 2008-2016 average in 2017 and were dramatically higher than average in 2018 (D. Lowry unpubl. data). Hake catch did not increase in 2015 when steelhead mortality began to decrease, and was highest in 2018 when steelhead mortality began to increase, but the abundant hake available to harbor seals in 2017 and 2018 may still have reduced predation pressure on steelhead and added to the buffering effect of anchovy. Predation impacts from transient killer whales on harbor seals and the increases in hake abundance may have had undocumented impacts on harbor 
seals, but did not correspond directly to the steelhead survival patterns presented in this study.

Generally, cool Pacific Ocean temperatures (negative PDO indices) are associated with lower marine mortality rates for Pacific salmon (Mantua et al. 1997, Daly \& Brodeur 2015). However, ocean temperature effects on Puget Sound steelhead smolt-to-adult return (SAR) rate appear to be opposite in sign, with warm-phase PDO years corresponding to lower steelhead mortality in marine waters, although largescale ocean indicators are not strong indicators of Puget Sound survival trends (Sobocinski et al. 2020). Recent evidence suggests that conditions within Puget Sound have a strong influence on steelhead SAR trends (Kendall et al. 2017), including a strong negative association of harbor seal population abundance and weak positive associations of the PDO and sea surface temperature in the Salish Sea (in the year of ocean entry) with Puget Sound smolt-to-adult steelhead survival rates (Sobocinski et al. 2020). Early marine survival of Puget Sound steelhead may be driven by forage fish abundance and associated predator-prey dynamics, while Columbia River Chinook salmon, for example, gain important survival benefits from availability of energy-rich prey resources in the early ocean environment during cool years (Daly \& Brodeur 2015). It is likely that different ecological processes dominate in each unique habitat encountered throughout salmonid migration, and that the pressures exerted by these different ecological processes contribute unequally toward the total survival rate.

Other species of salmon (e.g. Chinook, coho) may also be affected by the same anchovy-related reductions in predation pressure that we observed in steelhead. Net-pen raised coho salmon smolts released in south Puget Sound were detected leaving Puget Sound at the JDF array at a much higher rate $(12 \%)$ in 2016 when anchovy abundance was high relative to the detection rate $(0 \%)$ of the same population released in 2006 when anchovies were not observed in high numbers (S. Steltzner unpubl. data). To our knowledge, early marine survival rates of other salmon species have not been quantified in Puget Sound for annual comparison, making it difficult to speculate on the impact of anchovy on other species. Chinook smolts may benefit from some degree of reduced predation, but the relationship may be more complicated because this species occupies marine habitat in Puget Sound for a much longer period than the $2 \mathrm{wk}$ period observed for steelhead (Duffy et al. 2005). Other ecological interactions, including competition and density-depen- dent survival, for example, may outweigh or offset the benefits of reduced predation pressure due to abundant alternative prey.

Long-term ocean biological data sets are essential for understanding climate change impacts on marine ecosystems. Anchovy population dynamics in the Salish Sea may be shifting from episodic to more sustained as a result of continued warming, just one example among other ecological changes that are likely to affect early marine survival of steelhead and other salmonids. Anchovies in Puget Sound persisted into 2018 even though the marine heat wave technically subsided in 2016, likely because Puget Sound remained sufficiently warm to support anchovy spawning and recruitment. The shifting predatorprey dynamics and physiological processes caused by warming marine temperatures will affect different species in unpredictable ways. Some species will benefit from these shifts, while others may have less success under new conditions. By documenting the interacting environmental and trophic mechanisms governing steelhead survival and productivity in a fluctuating ecosystem, informed management and targeted recovery strategies can be developed to benefit threatened Puget Sound steelhead populations. Ecosystem-based management, specifically focused on healthy forage fish populations and reduced predator impacts, will be important to consider as recovery actions are developed for Puget Sound steelhead.

Acknowledgements. We greatly appreciate the efforts of all those who helped with planning and executing hydrophone deployments and retrievals, fish tagging, and seal capture and tagging, namely Rob Endicott, Iris Kemp, Dyanna Lambourn, Josh Oliver, Jed Moore, Sayre Hodgson, Chris Ellings, Walker Duval, Tom Friedrich, Rene Bracero, Emiliano Perez, Sammy Stepetin, Scott Steltzner, Matt Klungle, Chris Frazier, Justin Miller, Matt Pollack, and Katy Doctor. In addition to leading the seal tagging efforts, Steve Jeffries provided the seal data in Table S1. Surface trawling in Skagit Bay was funded through the Skagit Intensively Monitored Watersheds Project by the Washington State Recreation and Conservation Office. We thank the many staff and volunteers who supported the long-term monitoring effort, particularly Casey Rice, Anna Kagley, Dan Lomax, Josh Chamberlin, Jason Hall, and Craig Wollum. Special thanks to the Salish Sea Marine Survival Project Steelhead Technical Team for critical discussion and project support. This is Publication Number 49 from the Salish Sea Marine Survival Project: an international, collaborative research effort designed to determine the primary factors affecting the survival of juvenile Chinook salmon, coho salmon, and steelhead in the combined marine waters of Puget Sound and Strait of Georgia (marinesurvivalproject.com). Finally, we appreciate the time and insight of 4 anonymous reviewers, whose feedback greatly improved the clarity and quality of this paper. 


\section{LITERATURE CITED}

Auth TD, Daly EA, Brodeur RD, Fisher JL (2018) Phenological and distributional shifts in ichthyoplankton associated with recent warming in the northeast Pacific Ocean. Glob Change Biol 24:259-272

Bakun A (2006) Wasp-waist populations and marine ecosystem dynamics: navigating the 'predator pit' topographies. Prog Oceanogr 68:271-288

Balfry S, Welch DW, Atkinson J, Lill A, Vincent S (2011) The effect of hatchery release strategy on marine migratory behaviour and apparent survival of Seymour River steelhead smolts (Oncorhynchus mykiss). PLOS ONE 6:e14779

Barton K (2020) MuMIn: multi-model inference. R package version 1.43.17. https://CRAN.R-project.org/package $=$ MuMIn

Beamish RJ, Sweeting RM, Neville CM (2004) Improvement of juvenile Pacific salmon production in a regional ecosystem after the 1998 climatic regime shift. Trans Am Fish Soc 133:1163-1175

Berejikian BA, Moore ME, Jeffries SJ (2016) Predator-prey interactions between harbor seals and migrating steelhead trout smolts revealed by acoustic telemetry. Mar Ecol Prog Ser 543:21-35

Bolin RL (1936) Embryonic and early larval stage of the California anchovy. Calif Fish Game 22:314-321

Bradford MJ, Cabana G (1997) Interannual variability in stage-specific survival rates and the causes of recruitment variation. In: Chambers RC, Trippel EA (eds) Early life history and recruitment in fish populations. Chapman \& Hall, London, p 469-493

Brewer GD (1976) Thermal tolerance and resistance of the northern anchovy, Engraulis mordax. Fish Bull 74: 433-445

Brodeur RD, Gadomski DM, Pearcy WG, Batchelder HP, Miller CB (1985) Abundance and distribution of ichthyoplankton in the upwelling zone off Oregon during anomalous El Niño conditions. Estuar Coast Shelf Sci 21: 365-378

Brodeur RD, Ralston S, Emmet RL, Trudel M, Auth TD, Phillips AJ (2006) Anomalous pelagic nekton abundance, distribution, and apparent recruitment in the northern California Current in 2004 and 2005. Geophys Res Lett 33:L22S08

Brown RF, Mate BR (1983) Abundance, movements, and feeding-habits of harbor seals, Phoca vitulina, at Netarts and Tillamook Bays, Oregon. Fish Bull 81:291-301

Cavole LM, Demko AM, Diner RE, Giddings A and others (2016) Biological impacts of the 2013-2015 warm-water anomaly in the Northeast Pacific: winners, losers, and the future. Oceanography 29:273-285

* Chasco BE, Kaplan IC, Thomas AC, Acevedo-Gutiérrez A and others (2017) Estimates of Chinook salmon consumption in Washington State inland waters by four marine mammal predators from 1970 to 2015. Can J Fish Aquat Sci 74:1173-1194

Chavez FP, Ryan J, Lluca-Cota SE, Niquen M (2003) From anchovies to sardines and back: multidecadal change in the Pacific Ocean. Science 299:217-221

* Clark WG, Hare SR (2002) Effects of climate and stock size on recruitment and growth of Pacific halibut. N Am J Fish Manag 22:852-862

Cormack RM (1964) Estimates of survival from the sighting of marked animals. Biometrika 51:429-438
Daly EA, Brodeur RD (2015) Warming ocean conditions relate to increased trophic requirements of threatened and endangered salmon. PLOS ONE 10:e0144066

* Daly EA, Brodeur RD, Auth TD (2017) Anomalous ocean conditions in 2015: impacts on spring Chinook salmon and their prey field. Mar Ecol Prog Ser 566:169-182

Di Lorenzo E, Mantua N (2016) Multi-year persistence of the 2014/2015 North Pacific marine heatwave. Nat Clim Change 6:1042-1047

*Doney SC, Ruckelshaus M, Duffy JE, Barry JP and others (2012) Climate change impacts on marine ecosystems. Annu Rev Mar Sci 4:11-37

Doyle MJ (1995) The El Niño of 1983 as reflected in the ichthyoplankton off Washington, Oregon, and northern California. Can Spec Publ Fish Aquat Sci 121:161-180

*Du X, Peterson WT (2018) Phytoplankton community structure in 2011-2013 compared to the extratropical warming event of 2014-2015. Geophys Res Lett 45:1534-1540

Duffy EJ, Beauchamp DA, Buckley RM (2005) Early marine life history of juvenile Pacific salmon in two regions of Puget Sound. Estuar Coast Shelf Sci 64:94-107

* Duguid WDP, Boldt JL, Chalifour L, Greene CM and others (2019) Historical fluctuations and recent observations of northern anchovy Engraulis mordax in the Salish Sea. Deep Sea Res II 159:22-41

Fletcher D (2012) Estimating overdispersion when fitting a generalized linear model to sparse data. Biometrika 99: 230-237

Friedland KD, Dannewitz J, Romakkaniemi A, Palm S, Pulkkinen H, Pakarinen T, Oeberst R (2017) Post-smolt survival of Baltic salmon in context to changing environmental conditions and predators. ICES J Mar Sci 74:1344-1355

*Greene CM, Kuehne L, Rice C, Fresh K, Pentilla D (2015) Forty years of change in forage fish and jellyfish abundance across greater Puget Sound, Washington (USA): anthropogenic and climate associations. Mar Ecol Prog Ser 525:153-170

*Hare SJ, Mantua NJ, Francis RC (1999) Inverse production regimes: Alaska and West Coast Pacific salmon. Fisheries 24:6-14

Hazel J (2009) Evaluation of fast-acquisition GPS in stationary tests and fine-scale tracking of green turtles. J Exp Mar Biol Ecol 374:58-68

KHoude ED (1994) Differences between marine and freshwater fish larvae: implications for recruitment. ICES J Mar Sci 51:91-97

*Houghton J, Baird RW, Emmons CK, Hanson MB (2015) Changes in the occurrence and behavior of mammal-eating killer whales in southern British Columbia and Washington State, 1987-2010. Northwest Sci 89:154-169

Jacox MG, Alexander MA, Mantua NJ, Scott JD, Hervieux G, Webb RS, Werner FE (2018) Forcing of multiyear extreme ocean temperatures that impacted California Current living marine resources in 2016. Bull Am Meteorol Soc 99:S27-S33

Jeffries S, Huber H, Calambokidis J, Laake J (2003) Trends and status of harbor seals in Washington State: 19781999. J Wildl Manag 67:207-218

Jolly GM (1965) Explicit estimates from capture-recapture data with both death and immigration: stochastic model. Biometrika 52:225-247

Keister JE, Di Lorenzo E, Morgan CA, Combes V, Peterson WT (2011) Zooplankton species composition is linked to ocean transport in the Northern California Current. Glob Change Biol 17:2498-2511 
Kendall NW, Marston GW, Klungle MM (2017) Declining patterns of Pacific Northwest steelhead trout (Oncorhynchus mykiss) adult abundance and smolt survival in the ocean. Can J Fish Aquat Sci 74:1275-1290

Kilduff DP, Botsford LW, Teo SLH (2014) Spatial and temporal covariability in early ocean survival of Chinook salmon (Oncorhynchus tshawytscha) along the west coast of North America. ICES J Mar Sci 71:1671-1682

Laake JL (2013) RMark: an R interface for analysis of capture-recapture data with MARK. AFSC Processed Rep 2013-01. Alaska Fisheries Science Center, NOAA, NMFS, Seattle, WA

Lance MM, Chang WY, Jeffries SJ, Pearson SF, AcevedoGutiérrez A (2012) Harbor seal diet in northern Puget Sound: implications for the recovery of depressed fish stocks. Mar Ecol Prog Ser 464:257-271

Leising AW, Schroeder ID, Bograd SJ, Abell J and others (2015) State of the California Current 2014-2015. Impacts of the warm-water 'blob'. Calif Coop Ocean Fish Invest Rep 56:31-68

Lindegren M, Checkley DM Jr, Rouyer T, MacCall AD, Stenseth NC (2013) Climate, fishing, and fluctuations of sardine and anchovy in the California Current. Proc Natl Acad Sci USA 110:13672-13677

Lindgren F, Rue H (2015) Bayesian spatial modelling with RINLA. J Stat Softw 63:1-25

Litz MNC, Heppell SS, Rmmett RL, Brodeur RD (2008) Ecology and distribution of the northern subpopulation of northern anchovy (Engraulis mordax) off the US west coast. Calif Coop Ocean Fish Invest Rep 49:167-182

Litzow MA, Cianelli L, Puerta P, Wettstein JJ, Rykaczewski RR, Opiekun M (2018) Non-stationary climate-salmon relationships in the Gulf of Alaska. Proc R Soc B 285: 20181855

London JM (2006) Harbor seals in Hood Canal: predators and prey. $\mathrm{PhD}$ dissertation, University of Washington, Seattle, WA

Losee JP, Kendall NW, Dufault A (2019) Changing salmon: an analysis of body mass, abundance, survival, and productivity trends across 45 years in Puget Sound. Fish Fish 20:934-951

* Lowry LF, Frost KJ, Ver Hoef DM, DeLong RA (2001) Movements of satellite-tagged subadult and adult harbor seals in Prince William Sound, Alaska. Mar Mamm Sci 17: 835-861

Malick MJ, Cox SP, Mueter FJ, Dorner B, Peterman RM (2017) Effects of the North Pacific Current on the productivity of 163 Pacific salmon stocks. Fish Oceanogr 26: 268-281

Mantua NJ, Hare SR (2002) The Pacific Decadal Oscillation. J Oceanogr 58:35-44

KMantua NJ, Hare SR, Zhang Y, Wallace JM, Francis RC (1997) A Pacific interdecadal climate oscillation with impacts on salmon production. Bull Am Meteorol Soc 78: 1069-1080

Melnychuk MC (2009) Mortality of migrating Pacific salmon smolts in Southern British Columbia, Canada. $\mathrm{PhD}$ dissertation. University of British Columbia, Vancouver

* Melnychuk MC, Christensen VC, Walters CJ (2013) Mesoscale movement and mortality patterns of juvenile coho salmon and steelhead trout migrating through a coastal fjord. Environ Biol Fishes 96:325-339

Melnychuk MC, Korman J, Hausch S, Welch DW, McCubbing DJF, Walter CJ (2014) Marine survival differences between wild and hatchery-reared steelhead trout determined during early downstream migration. Can J Fish Aquat Sci 71:831-846

* Menge BA, Chan FC, Nielsen KJ, Di Lorenzo E, Lubchenco J (2009) Climatic variation alters supply-side ecology: impact of climate patterns on phytoplankton and mussel recruitment. Ecol Monogr 79:379-395

*Moore ME, Berejikian BA (2017) Population, habitat, and marine location effects on early marine survival and behavior of Puget Sound steelhead smolts. Ecosphere 8: e01834

*Moore ME, Berejikian BA, Goetz FA, Berger AG, Hodgson SS, Connor EJ, Quinn TP (2015) Multi-population analysis of Puget Sound steelhead survival and migration behavior. Mar Ecol Prog Ser 537:217-232

Mueter FJ, Peterman RM, Pyper BJ (2002) Opposite effects of ocean temperature on survival rates of 120 stocks of Pacific salmon (Oncorhynchus spp.) in northern and southern areas. Can J Fish Aquat Sci 59:456-463

* Munsch SH, Greene CM, Johnson RC, Satterthwaite WH, Imaki H, Brandes PL (2019) Warm, dry winters truncate timing and size distribution of seaward-migrating salmon across a large, regulated watershed. Ecol Appl 29:e01880

Olesiuk PF (1993) Annual prey consumption by harbor seals (Phoca vitulina) in the Strait of Georgia, British Columbia. Fish Bull 91:491-515

Olsen J, Wood J, Osborne R, Otis R (2019) Final program report: SRKW sighting compilation, $15^{\text {th }}$ edn. The Whale Museum, Friday Harbor, WA

Pearson SF, Jeffries SJ, Lance MM, Thomas AC (2015) Identifying potential juvenile steelhead predators in the marine waters of the Salish Sea. Washington Department of Fish and Wildlife, Wildlife Science Division, Olympia, WA

*Peterson SH, Lance MM, Jeffries SJ, Acevedo-Gutiérrez A (2012) Long distance movements and disjunct spatial use of harbor seals (Phoca vitulina) in the inland waters of the Pacific Northwest. PLOS ONE 7:e39046

* Peterson WT, Fisher JL, Strub PT, Du X, Risien C, Peterson J, Shaw CT (2017) The pelagic ecosystem in the Northern California Current off Oregon during the 2014-2016 warm anomalies within the context of the past 20 years. J Geophys Res Oceans 122:7267-7290

Pike GC (1951) Age, growth and maturity studies on the Pacific anchovy (Engraulis mordax) from the coast of British Columbia. MSc thesis, University of British Columbia, Vancouver

*Poloczanska ES, Burrows MT, Brown CJ, García Molinos J and others (2016) Responses of marine organisms to climate change across oceans. Front Mar Sci 3:62

Puget Sound Steelhead Marine Survival Workgroup (2018) Salish Sea Marine Survival Project-Puget Sound Steelhead Marine Survival: 2013-2017 research findings summary. Long Live the Kings, Seattle, WA. www. marinesurvivalproject.com

R Core Team (2019) R: a language and environment for statistical computing. R Foundation for Statistical Computing, Vienna

Rice CA, Greene CM, Moran P, Teel DJ and others (2011) Abundance, stock origin, and length of marked and unmarked juvenile Chinook salmon in the surface waters of greater Puget Sound. Trans Am Fish Soc 140:170-189

Rice CA, Duda JJ, Greene CM, Karr JR (2012) Geographic patterns of fishes and jellyfish in Puget Sound surface waters. Mar Coast Fish 4:117-128 
Rice J (1995) Food web theory, marine food webs, and what climate change may do to northern fish populations. Can Spec Publ Fish Aquat Sci 121:561-568

Richardson SL (1973) Abundance and distribution of larval fishes in waters off Oregon, May-October 1969, with special emphasis on the northern anchovy, Engraulis mordax. Fish Bull 71:697-711

Ricker WE (1975) Computation and interpretation of biological statistics of fish populations. Bull Fish Res Board Can 191:1-182

Rue H, Martino S, Chopin N (2009) Approximate Bayesian inference for latent Gaussian models by using integrated nested Laplace approximations. J R Stat Soc Ser B Stat Methodol 71:319-392

Ruggerone GT, Goetz FA (2004) Survival of Puget Sound Chinook salmon (Oncorhynchus tshawytscha) in response to climate-induced competition with pink salmon (Oncorhynchus gorbuscha). Can J Fish Aquat Sci 61: 1756-1770

Seber GA (1965) A note on the multiple-recapture census. Biometrika 52:249-259

* Sharma R, Vélez-Espino LA, Wertheimer AC, Mantua N, Francis RC (2013) Relating spatial and temporal scales of climate and ocean variability to survival of Pacific Northwest Chinook salmon (Oncorhynchus tshawytscha). Fish Oceanogr 22:14-31

Shields MW, Hysong-Shimazu S, Shields JC, Woodruff J (2018) Increased presence of mammal-eating killer whales in the Salish Sea with implications for predator-prey dynamics. PeerJ 6:e6062

Siple MC, Francis TB (2016) Population diversity in Pacific herring of the Puget Sound, USA. Oecologia 180: 111-125

Editorial responsibility: Franz Mueter,

Juneau, Alaska, USA

Reviewed by: 2 anonymous referees
Sobocinski KL, Kendall NW, Greene CM, Schmidt MW (2020) Ecosystem indicators of marine survival in Puget Sound steelhead trout. Prog Oceanogr 188:102419

Sydeman WJ, Santora JA, Thompson SA, Marinovic B, Di Lorenzo E (2013) Increasing variance in North Pacific climate relates to unprecedented ecosystem variability off California. Glob Change Biol 19:1662-1675

Teo SLH, Botsford LW, Hastings A (2009) Spatio-temporal covariability in coho salmon (Oncorhynchus kisutch) survival, from California to southeast Alaska. Deep Sea Res II 56:2570-2578

* Thomas AC, Nelson BW, Lance MM, Deagle BE, Trites AW (2017) Harbour seals target juvenile salmon of conservation concern. Can J Fish Aquat Sci 74:907-921

Thomas AC, Deagle B, Nordstrom C, Majewski S and others (in press) Harbor seal DNA metabarcoding diet data of the Salish Sea. Scientific Data

*Thompson SA, Sydeman WJ, Santora JA, Black BA and others (2012) Linking predators to seasonality of upwelling: using food web indicators and path analysis to infer trophic connections. Prog Oceanogr 101:106-120

*Welch DW, Ward BR, Smith BD, Eveson JP (2000) Temporal and spatial responses of British Columbia steelhead (Oncorhynchus mykiss) populations to ocean climate shifts. Fish Oceanogr 9:17-32

*Wells BK, Santora JA, Henderson MJ, Warzybok P and others (2017) Environmental conditions and prey-switching by a seabird predator impact juvenile salmon survival. J Mar Syst 174:54-63

* Zimmerman MS, Irvine JR, O'Neill M, Anderson JH and others (2015) Spatial and temporal patterns in smolt survival of wild and hatchery coho salmon in the Salish Sea. Mar Coast Fish 7:116-134

Submitted: September 4, 2020

Accepted: December 3, 2020

Proofs received from author(s): March 2, 2021 